\title{
Pemanfaatan Layanan Perpustakaan dan Prestasi Akademis Mahasiswa
}

\author{
Samiyati ${ }^{1}$, Isti Suratmi ${ }^{2}$, Jody Santoso ${ }^{3}$ \\ ${ }^{1,2,3}$ UPT Perpustakaan Institut Seni Indonesia Yogyakarta \\ Jalan Parangtritis km. 6,5 Yogyakarta \\ HP.: 0817462351; Email: samiyati@gmail.com
}

\begin{abstract}
Abstrak
Penelitian ini membahas pemanfaatan layanan perpustakaan kaitannya dengan prestasi akademis mahasiswa di FSMR ISI Yogyakarta. Tujuan penelitian untuk mengetahui pemanfaatan layanan perpustakaan terhadap pencapaian prestasi akademis mahasiswa. Metode penelitian yang digunakan bersifat deskriptif dengan pendekatan kuantitatif menggunakan Skala Likert. Dari hasil penelitian ini diketahui, bahwa: mahasiswa memanfaatkan layanan perpustakaan sebagian besar untuk meminjam buku, dan mengerjakan tugas kuliah. Pencapaian IPK mahasiswa cukup tinggi dengan IPK terendah 2.83, tertinggi 3.91, dan rata-rata 3.37. Pemanfaatan layanan perpustakaan mempunyai hubungan positif yang rendah dengan prestasi akademis mahasiswa. Artinya, pemanfaatan layanan perpustakaan tidak berpengaruh signifikan dengan prestasi akademis, besaran pengaruh tersebut adalah $0.1 \%$. Mahasiswa FSMR, sesuai lingkup akademis yang dipelajari, mempunyai akses informasi yang luas sehingga prestasi mereka tidak hanya tergantung pada layanan perpustakaan. Dalam proses pembelajaran mereka dituntut menghasilkan karya akademis yang dipelajari dengan praktek langsung di lapangan. Rekomendasi penelitian agar perpustakaan: secara periodik mengevaluasi kebijakan terkait layanan disesuaikan dengan kebutuhan, menjalin kerjasama dengan berbagai pihak yang mendukung pembelajaran mahasiswa, menggiatkan sosialisasi layanan, dan menambah fasilitas yang relevan dengan kebutuhan pemustaka.
\end{abstract}

Kata kunci: perpustakaan; layanan; prestasi akademis; mahasiswa

\begin{abstract}
The Utilization of Library Services and Student Academic Achievement. This research discusses the utilization of library services related to students' academic achievement at FSMR ISI Yogyakarta. The purpose of research is to find out the utilization of library services to the triumph of academic achievement of students. The research methods used are descriptive with a quantitative approach using the Likert Scale. From the results of this study, it is known that: students use library services mainly to borrow books and do college assignments. Student GPA achievement is relatively high with the lowest GPA of 2.83, highest 3.91, and the average of 3.37. The use of library services has a low positive relationship with students' academic performance. The utilization of library services has no significant effect on academic achievement; the amount of influence is $0.1 \%$. FSMR students, according to the intellectual scope studied, have access to extensive information so that their accomplishments are not only dependent on their achievements. In the learning process they are required to produce academic work that is learned by direct practice in the field. Research recommendations for libraries: periodically evaluate policies related to services tailored to their needs, establish cooperation with various parties that support student learning, promote service socialization, and add facilities that are relevant to the needs of users.
\end{abstract}

Keywords: library; service; academic achievement; students 


\section{A. Pendahuluan}

Perpustakaan perguruan tinggi memiliki peran penting dalam mewujudkan sumber daya manusia yang berkualitas, mandiri, dan mampu berdaya saing. Perpustakaan diharapkan mempunyai kontribusi nyata dalam membangun masyarakat berpengetahuan (knowledge society). Kontribusi perpustakaan perguruan tinggi dapat dilihat dari seberapa besar perannya dalam meningkatkan kualitas pengetahuan civitas akademika yang dilayani. Salah satu isu mendasar yang kini dialami oleh berbagai perpustakaan perguruan tinggi adalah "value of libraries". Apa sebenarnya nilai dan makna sebuah perpustakaan perguruan tinggi?

Sebuah riset yang dilakukan Laughborough University di Inggris menemukan bahwa di hampir semua negara Eropa dan Amerika, perpustakaan perguruan tinggi didorong aktif mengumpulkan bukti-bukti konkrit dari peran mereka (Rodin, 2019: 84). Bukan saja bukti aktivitas melainkan bukti nilai dan pengaruh dari kegiatan itu terhadap misi perguruan tinggi di mana mereka berada. Hal senada juga juga disyaratkan dalam penilaian akreditasi perpustakaan perguruan tinggi terbaru, yaitu setiap perpustakaan harus melakukan survei dampak pelayanan perpustakaan terhadap perkembangan prestasi akademis dalam tiga tahun terakhir. UPT Perpustakaan ISI Yogyakarta memenuhi tuntutan ini untuk mempertahankan akreditasi dengan nilai A selama dua kali berturutturut.

Sebagai perpustakaan perguruan tinggi, UPT Perpustakaan ISI Yogyakarta selalu meningkatkan layanan kepada pemustaka. Layanan di UPT Perpustakaan ISI Yogyakarta jika ingin terus digunakan dan dihargai pemustaka dan masyarakat penggunanya maka perlu ada inovasi dan peningkatan kualitas layanan yang diberikan dengan terus mengevaluasi diri dan penambahan sarana-prasarana yang dibutuhkan para pemustaka sehingga pada akhirnya dengan diperoleh citra yang baik terhadap perpustakaan serta dapat memuaskan masyarakat publik sebagai penggunanya. Di dalam mengevaluasi diri ini dengan diperoleh gambaran mengenai kelemahan dan potensi yang ada di perpustakaan yang pada akhirnya kelemahan yang ada dapat diperbaiki dan potensi yang ada dapat diberdayakan secara maksimal (Agustiawan, 2018: 4). Tujuan lain dari peningkatan layanan adalah turut serta mewujudkan masyarakat akademik yang berkualitas. Salah satu tolak ukur untuk menilai kualitas pembelajaran di perguruan tinggi adalah dengan melihat prestasi akademis mahasiswa. Layanan perpustakaan sering dijadikan sebagai patokan berhasil tidaknya pengelolaan perpustakaan. Layanan perpustakaan, menurut Istiana (2014:1), adalah penyediaan bahan pustaka dan atau sumber informasi secara tepat serta penyediaan berbagai layanan dan bantuan kepada pemustaka sesuai kebutuhannya. Seiring dengan kemajuan teknologi dan perkembangan perpustakaan, fasilitas yang dapat dimanfaatkan dalam menyajikan berbagai jenis jasa layanan perpustakaan semakin beragam.

Institut Seni Indonesia Yogyakarta mempunyai Fakultas Seni Media Rekam (FSMR). Fakultas ini keberadaannya paling baru diantara tiga fakultas lain, yaitu: Fakultas Seni Rupa (FSR) dan Fakultas Seni Pertunjukan (FSP). FSMR ISI Yogyakarta dibentuk atas dasar Keputusan Menteri Pendidikan dan Kebudayaan Nomor 0373/0/1993 tanggal 21 Oktober 1993. Setelah lebih dari 26 tahun, perkembangan FSMR sebagai fakultas yang memiliki komitmen terhadap perkembangan bidang ilmu audiovisual sangat pesat. Program studi yang dimiliki adalah Film dan Televisi, Fotografi, dan Animasi dengan total keanggotaan di perpustakaan sebanyak 1.026 mahasiswa (Sumber: database online ISI Yogyakarta).

Berbeda dengan fakultas lain (FSR dan FSP) yang lebih mengarah pada penyediaan koleksi seni budaya tradisional dan kontemporer, FSMR mempunyai slogan memadukan kualitas intelektual dan kepekaan estetik yang disinergikan dengan kecanggihan teknologi. Kebutuhan bahan pustakanya pun berbeda. Mahasiswa FSMR membutuhkan koleksi bahan pustaka yang lebih modern, terutama yang berkaitan dengan komunikasi, kemajuan teknologi telekomunikasi dan informasi, tentu masih dalam lingkup yang berhubungan dengan masalah seni budaya.

Namun, kondisi faktual di UPT Perpustakaan ISI Yogyakarta menunjukkan bahwa tingkat 
pemanfaatan perpustakaan oleh mahasiswa FSMR masih rendah. Data statistik kunjungan fisik mahasiswa dari tahun 2017 sampai dengan 2019 yang terekam di perpustakaan menunjukkan bahwa rata-rata kunjungan mahasiswa FSMR sedikit. Kunjungan per tahun sebanyak 2.041 orang, jika diturunkan per bulan sebanyak 170 orang, dan per hari sebanyak 9 (sembilan) orang. Frekuensi kunjungan hanya sekitar 0,2\%. Artinya, antusiasme mahasiswa FSMR datang ke perpustakaan rendah. Disisi lain, penulis menyadari bahwa mahasiswa yang tidak datang secara fisik ke perpustakaan belum tentu tidak memanfaatkan koleksi perpustakaan karena beberapa koleksi yang dapat diakses secara daring. Misalnya koleksi tugas akhir dan koleksi penelitian yang dapat diakses dari rumah.

Tujuan penelitian ini untuk: (1) Mengetahui pemanfaatan layanan perpustakaan; (2) Mengetahui prestasi akademis mahasiswa FSMR ISI Yogyakarta yang memanfaatkan layanan perpustakaan; dan (3) Mengetahui ada tidaknya pengaruh pemanfaatan layanan perpustakaan terhadap prestasi akademik mahasiswa. Fokus penelitian ini adalah pada pengaruh pemanfaatan layanan perpustakaan terhadap prestasi akademis mahasiswa FSMR ISI Yogyakarta. Penelitian ini dirasa perlu selain untuk memenuhi tuntutan akreditasi perpustakaan selanjutnya, juga sebagai evaluasi intern perpustakaan yang sejalan dengan tujuan utama perpustakaan sebagai unit pendukung ISI Yogyakarta.

Saat ini, informasi mempunyai nilai yang sangat dan penting sebagai sumber daya strategis untuk pengembangan ilmu pengetahuan. Produk perpustakaan berupa koleksi baik cetak maupun elektronik dan layanan kepada pemustakaan. Gupta dan Jambhekar dalam Mardiastuti (2019: 214) menjelaskan produk dan layanan kedalam lima kategori, meliputi: terbitan berkala, bahan rujukan (referensi), buku perkuliahan baik tercetak maupun elektronik, koleksi lain-lain (dokumen pemerintah, peraturan perundang-undangan, dokumen multimedia, paten, proseding, karya ilmiah, dan data-data perusahaan), layanan perpustakaan (layanan informasi, peminjaman dan pengembalian, konsultasi bibliografi, dan pelatihan-pelatihan perpustakaan).
Layanan perpustakaan yang dimaksud dalam penelitian ini adalah layanan kepada pemustaka. Menurut Istiana (2014: 1), layanan perpustakaan adalah penyediaan bahan pustaka dan atau sumber informasi secara tepat serta penyediaan berbagai layanan dan bantuan kepada pemustaka sesuai kebutuhannya. Seiring dengan kemajuan teknologi dan perkembangan perpustakaan, maka fasilitas yang dapat dimanfaatkan dalam menyajikan berbagai jenis jasa layanan perpustakaan beragam.

Secara umum, tugas layanan perpustakaan adalah memberikan pelayanan, bimbingan, arahan agar pemustaka dapat memanfaatkan fasilitas perpustakaan dengan maksimal. Tujuan layanan perpustakaan perguruan tinggi menyajikan informasi untuk menunjang kegiatan Tri Dharma Perguruan Tinggi, yaitu: pendidikan, penelitian, dan pengabdian masyarakat. Perpustakaan diharapkan mampu memberikan layanan untuk mendukung proses pembelajaran mahasiswa. Jenis layanan perpustakaan dijalankan perpustakaan dengan pertimbangan, antara lain: sarana yang dimiliki perpustakaan, jumlah staf perpustakaan, luas sempitnya cakupan koleksi, serta kebutuhan pemustaka dengan jenis layanan tertentu. Layanan yang umum ada di perpustakaan perguruan tinggi, antara lain adalah layanan informasi, sirkulasi, referensi, karya ilmiah, keanggotaan, terbitan berkala, penelusuran informasi, fotokopi, pendidikan pemustaka, dan layanan digital.

Prestasi akademis, menurut KBBI daring, adalah hasil pelajaran yang diperoleh dari kegiatan belajar di sekolah atau perguruan tinggi yang bersifat kognitif dan biasanya ditentukan melalui pengukuran dan penilaian. Afiah (2012: 13) menyimpulkan bahwa prestasi akademik adalah besarnya penguasaan bahan pelajaran yang telah dicapai seseorang yang diwujudkan berupa nilai. Dalam penelitian ini, prestasi akademik dimaksudkan sebagai istilah yang yang menunjukkan suatu pencapaian tingkat keberhasilan pada suatu tujuan karena usaha belajar yang yang dilakukan mahasiswa secara optimal.

Menurut Slamet dalam Afiah (2012: 17) secara garis besar faktor yang mempengaruhi prestasi dapat digolongkan menjadi faktor internal dan faktor eksternal. Faktor internal berasal dari 
dalam diri seseorang, dibagi menjadi dua bagian, yaitu: faktor fisiologis dan faktor psikologis. Faktor fisiologis adalah faktor yang berhubungan dengan kesehatan dan pancaindera. Faktor psikologis berhubungan dengan masalah intelegensi, bakat, minat, motivasi, kemampuan kognitif (persepsi, daya ingat, berfikir, dan daya konsentrasi).

Faktor eksternal adalah faktor dari luar diri seseorang. Faktor dari luar, antara lain berasal dari: lingkungan keluarga, lingkungan akademis, dan lingkungan masyarakat. Faktor lingkungan keluarga dapat berupa: sosial ekonomi keluarga, pendidikan orang tua, dan perhatian dan hubungan antar anggota keluarga. Faktor lingkungan akademis, meliputi: sarana dan prasarana akademis, kompetensi guru, dan kurikulum dan metode mengajar. Faktor lingkungan masyarakat, berupa: sosial budaya dan partisipasi terhadap pendidikan.

Suryabrata dalam Afiah (2012: 36), menjelaskan karakteristik individu berpotensi akademik, yaitu: berfikir cepat-tepat, kaya dengan kosa kata, berfikir logis, berfikir analitis, dan cepat menangkap persoalan. Lebih jelas Delphie dalam Afiah (2012: 36-37), mengatakan bahwa individu berpotensi akademik mempunyai karakteristik: (1) Mempunyai kemampuan intelektual atau intelegensi yang meyeluruh, mengacu pada kemampuan berfikir secara abstrak dan mampu memecahkan masalah secara sistematis dan masuk akal; (2) Mempunyai kemampuan intelektual khusus, mengacu pada kemampuan yang berbeda dalam bidang eksakta maupun non eksakta; (3) Mempunyai daya pikir kreatif dan berfikir murni menyeluruh. Umumnya mampu berfikir untuk memecahkan masalah yang tidak umum dan memerlukan pemikiran tinggi. Pikiran kreatif menghasilkan ide-ide produktif melalui imajinasi kepintarannya, keluwesannya, dan bersifat menakjubkan.

\section{B. Metode Penelitian}

Penelitian ini menggunakan metode deskriptif dengan pendekatan kuantitatif. Bentuk penelitian yang digunakan adalah studi hubungan dengan maksud mencari ada atau tidaknya hubungan antara variabel bebas dan variabel terikat. Teknik pengumpulan data menggunakan kuesioner, observasi, dan dokumentasi. Pertanyaan dalam kuesioner disusun berdasarkan teori atau konsep yang diacu dalam penelitian yang dijabarkan dalam Skala Likert. Variabel penelitian yang digundengan dalam penelitian ini adalah: pemanfaatan layanan perpustakaan (variable $\mathrm{X}$ ) dan prestasi akademis mahasiswa (variable Y). Pemanfaatan layanan perpustakaan menggunakan indikator; mengerjakan tugas kuliah, memecahkan masalah proyek, membuat karya tulis, dan membuat karya seni. Sedangkan prestasi akademik menggunakan indikator indeks prestasi komulatif (IPK).

Populasi berjumlah 226 orang, yaitu ratarata pengunjung perpustakaan per bulan. Awalnya penelitian ini menggunakan tabel penentuan sampel yang dikembangkan oleh Isac dan Michael dengan tolerasi satu persen (Sujarweni, 2004: 68), sehingga ditentukan sampel awal sebesar 170 orang. Namun, kondisi pandemi menjadi salah satu penghalang bagi menulis untuk mendapatkan jumlah responden yang ideal. Dalam perjalanan penelitian, penulis berhasil mendapatkan responden sejumlah 118 orang. Jika dihitung dengan rumus penentuan sampel menurut Bungin (2005: 115), $\mathrm{n}=\mathrm{N} / \mathrm{N}(\mathrm{d})^{2}+1$, sampel yang didapat dalam penelitian ini mempunyai nilai presisi sekitar $6,4 \%$.

Kuesioner disebar dengan menggunakan google form karena situasi pandemi. Uji keabsahan data dalam penelitian ini menggunakan analisis regresi sederhana dan analisis korelasi. Analisis regresi sederhana dan analisis korelasi yang dilakukan menggunakan program excel dan SPSS 20. Populasi dalam penelitian ini adalah seluruh mahasiswa FSMR ISI Yogyakarta dan aktif memanfaatkan perpustakaan di tahun 2019.

\section{Hasil dan Pembahasan}

Hasil uji validitas variabel pemanfaatan layanan (X) menunjukkan bahwa semua pertanyaan kuesioner valid. Nilai $r_{\text {hitung }}$ lebih besar dari $r_{\text {tabel }} 0,181$. Jumlah pertanyaan kuesioner yang digunakan sebagai instrumen data ada 21 pertanyaan. Setelah dihitung dengan bantuan program SPSS 20, maka dapat diketahui nilai reliabilitas (cronbach's alpha) variabel Pemanfaat 
Layanan Perpustakaan (X) sebesar 0,916. Nilai ini lebih besar dari 0,600 maka alat ukur kuisioner reliabel atau telah memenuhi syarat reliabilitas. Deskripsi statistik variabel yang digundengan dalam penelitian diperoleh hasil bahwa pada variable Pemanfaatan Layanan, jumlah data 118, nilai minimum 42 , nilai maksimum 83 , rata-rata 61,53, dan standar deviasi 7,585. Sedangkan variable Prestasi Akademis jumlah data 118, nilai minimum 2,83, nilai maksimum 3,91, rata-rata 3,3771, dan standar deviasi 0,22227.

Pengujian regresi linier sederhana dapat dilakukan setelah model pada penelitian ini memenuhi syarat-syarat yaitu lolos dari uji asumsi klasik. Pengujian asumsi klasik diperlukan untuk mendeteksi ada atau tidaknya penyimpangan asumsi klasik atas persamaan regresi sederhana yang digundengan. Pengujian asumsi klasik pada regresi linier sederhana untuk data kuisioner terdiri atas uji normalitas dan heteroskedastisitas. Dari hasil penelitian diketahui bahwa nilai signifikansi (Asym.sig 2 tailed) sebesar 0,382. Karena nilai lebih dari 0,05 , jadi residual terdistribusi normal. Pada hasil uji heteroskedastisitas menunjukkan bahwa titik-titik menyebar dengan pola yang tidak jelas diatas dan dibawah angka 0 pada sumbu Y. Jadi dapat disimpulkan bahwa tidak terjadi masalah heterokedastisitas pada model regresi.

Dari uji persamaan regresi linier sederhana yang diolah dengan bantuan program SPSS diperoleh data pada tabel 1 .

Persamaan regresinya sebagai berikut:

$$
\mathrm{Y}=3,317+0,001 \mathrm{X}
$$

- Konstanta sebesar 3,317; artinya jika pemanfaatan layanan perpustakaan nilainya adalah 0 , maka prestasi akademis mahasiswa nilainya sebesar 3,317.

- Koefisien regresi variabel Pemanfaatan Layanan

Tabel 1. Data uji persamaan regresi linier sederhana.

\begin{tabular}{|c|c|c|c|c|c|}
\hline \multicolumn{6}{|c|}{ Coefficients $^{\mathrm{a}}$} \\
\hline \multirow{2}{*}{ Model } & $\begin{array}{r}\text { Unstan } \\
\text { Coeff } \\
\end{array}$ & $\begin{array}{l}\text { darized } \\
\text { cients }\end{array}$ & $\begin{array}{l}\text { Standarized } \\
\text { Coefficients }\end{array}$ & \multirow{2}{*}{$\mathrm{t}$} & \multirow{2}{*}{ Sig. } \\
\hline & B & $\begin{array}{l}\text { Std. } \\
\text { Error }\end{array}$ & Beta & & \\
\hline \multirow{2}{*}{$\begin{array}{l}1 \text { (Constant) } \\
\text { Pemanfaatan } \\
\text { Layanan }\end{array}$} & 3.317 & 0.169 & & 19.667 & 0.000 \\
\hline & 0.001 & 0.003 & 0.034 & 0.362 & 0.178 \\
\hline
\end{tabular}

${ }^{a}$ Dependent variable: Prestasi Akademik.
Perpustakaan $(\mathrm{X})$ sebesar 0,001; artinya setiap peningkatan pemanfaatan layanan perpustakaan sebesar 1 (satu) satuan, maka dengan meningkatkan prestasi akademis mahasiswa sebesar 0,001 satuan.

Hasil analisis determinasi $\left(\mathrm{R}^{2}\right)$ yang diperoleh setelah data diolah disajikan dalam tabel 2 .

Berdasarkan tabel diperoleh nilai $\mathrm{R}^{2}$ sebesar $0,001(0,1 \%)$. Hal ini menunjukkan bahwa variasi variabel independen yang digundengan dalam model (Pemanfaatan Layanan Perpustakaan) mampu menjelaskan sebesar $0,1 \%$ variasi variabel prestasi akademis mahasiswa, dan sisanya dijelaskan oleh variabel lain yang tidak dimasukkan dalam model penelitian ini. Untuk membuktikan apakah terdapat hubungan yang signifikan atau tidak antara pemanfaatan layanan perpustakaan dengan prestasi akademis dilakukan uji signifikansi korelasi. Dari output dapat diketahui nilai Sig (Signifikansi) sebesar 0,718. Karena nilai signifikan lebih dari 0,05 maka dapat disimpulkan tidak ada hubungan yang signifikan antara pemanfaatan layanan perpustakaan dengan prestasi akademis mahasiswa FSMR ISI Yogyakarta.

Responden penelitian dipilih berdasarkan keaktifan mereka memanfaatkan layanan perpustakaan. Artinya, dari awal mereka sudah memanfaatkan layanan perpustakaan. Hasil analisis regresi linear sederhana dan uji hipotesis menunjukkan bahwa pemanfaatan layanan perpustakaan tidak berpengaruh signifikan terhadap prestasi akademis mahasiswa FSMR ISI Yogyakarta. Hal ini berdasar uji t yang didapat nilai $\mathrm{t}_{\text {hitung }}<\mathrm{t}_{\text {tabel }}(0,362<1,981)$ atau signifikansi $>0,05$ $(0,718>0,05)$, maka Ho diterima dan Ha ditolak. Hasil analisis korelasi juga menunjukkan bahwa pemanfaatan layanan perpustakaan memiliki hubungan positif yang sangat rendah dengan prestasi akademis mahasiswa (nilai korelasi 0,034). Nilai positif artinya semakin tinggi pemanfaatan

Tabel 2. Hasil analisis determinasi $\left(\mathrm{R}^{2}\right)$.

\begin{tabular}{lccccc}
\multicolumn{6}{c}{ Model Summary $^{\mathrm{b}}$} \\
\hline Model & $\mathrm{R}$ & R Square & $\begin{array}{c}\text { Adjusted } \\
\text { R Square }\end{array}$ & $\begin{array}{c}\text { Std. Error } \\
\text { of the } \\
\text { Estimate }\end{array}$ & $\begin{array}{c}\text { Durbin - } \\
\text { Watson }\end{array}$ \\
\hline 1 & $0.034^{\mathrm{a}}$ & 0.001 & -0.007 & 0.22310 & 2.124 \\
\hline $\begin{array}{l}{ }^{\mathrm{a}} \text { Predictors: (Constant), Pemanfaatan Layanan. } \\
{ }^{\mathrm{b}} \text { Dependent Variable: Prestasi Akademik. }\end{array}$
\end{tabular}


layanan perpustakaan maka semakin tinggi pula prestasi akademis mahasiswa, dan sebaliknya semakin rendah pemanfaatan layanan perpustakaan maka semakin rendah pula prestasi akademis mahasiswa.

Uji signifikansi korelasi dilakukan untuk membuktikan apakah ada hubungan signifikan atau tidak antara pemanfaatan layanan perpustakaan dengan prestasi akademis. Dari output dapat diketahui nilai Sig (Signifikansi) sebesar 0,718. Karena nilai signifikan lebih dari 0,05 maka dapat disimpulkan tidak ada hubungan yang signifikan antara pemanfaatan layanan perpustakaan dengan prestasi akademis mahasiswa FSMR ISI Yogyakarta. Sedangkan dari hasil analisis koefisien determinasi diketahui bahwa nilai $\mathrm{R}^{2}$ sebesar $0,001(0,1 \%)$. Hal ini menunjukkan bahwa variasi variabel independen yang digundengan dalam model (pemanfaatan pelayanan perpustakaan) mampu menjelaskan sebesar $0,1 \%$ variasi variabel prestasi akademis mahasiswa, dan sisanya dijelaskan oleh variabel lain yang tidak dimasukkan dalam model penelitian ini.

Hasil penelitian ini menunjukkan bahwa pemanfaatan layanan perpustakaan tidak berpengaruh signifikan dengan prestasi akademis mahasiswa. Besaran pengaruh tersebut sebesar 0.1\%. Mahasiswa FSMR, sesuai lingkup akademis yang dipelajari, mempunyai akses informasi yang luas sehingga prestasi mereka tidak hanya tergantung pada layanan perpustakaan. Dalam proses pembelajaran mereka dituntut menghasilkan karya akademis yang dipelajari dengan praktek langsung di lapangan.

Penelitian ini juga menggali masukan dari responden berupa pertanyaan terbuka untuk mengoptimalkan layanan perpustakaan dimasa yang dengan datang. Masukan yang diberikan responden untuk UPT Perpustakaan ISI Yogyakarta berkaitan dengan harapan mereka pada peningkatan layanan perpustakaan. Peningkatan layanan perpustakaan diharapkan mempunyai korelasi yang positif dengan pemanfaatan layanan yang dapat menunjang prestasi akademis mahasiswa. Dalam penelitian ini, responden memberi masukan tentang layanan di perpustakaan. Masukan dari responden berkaitan dengan beberapa hal, antara lain: regulasi, layanan, kelengkapan koleksi, penyajian koleksi, dan fasilitas dan kenyamanan tempat.

Masukan responden yang berkaitan dengan regulasi perpustakaan, yaitu; penambahan jam buka layanan, peraturan larangan membawa barang pribadi ke ruangan perlu ditinjau kembali, akses peminjaman buku dipermudah di masa pandemi, akses koleksi digital dipermudah dengan menampilkannya secara full text, perpanjangan waktu pinjam, dan keringanan biaya keterlambatan. Secara umum layanan sudah dinilai baik. Masukan yang berhubungan layanan, yaitu: peningkatan keramahan petugas, akses langsung ke perpustakaan dengan segera dibukanya layanan terbuka.

Dalam kaitannya dengan koleksi, responden memberi masukan agar perpustakaan: menambah koleksi digital, meng-update koleksi baru, dan perlu tambahan referensi bacaan pendukung diluar subjek seni. Penyajian koleksi menurut responden perlu peningkatan, terutama dalam hal penempatan buku sesuai katalog, penambahan koleksi digital agar dapat diakses secara daring, penyajian koleksi baruperlu ditonjolkan, dan penanganan buku-buku lama, baik dengan penyiangan maupun perawatan. Masalah fasilitas dan kenyamanan perpustakaan juga menjadi sorotan responden. Mereka mengusulkan agar perpustakaan menyediakan ruang interaktif, memperhatilkan penempatan tempat sampah, menambah pendingin ruangan (AC), menambah estetika ruang, memperhatikan kenyamanan area baca, menambah colokan listrik, dan membuat ruang caffee break.

\section{Kesimpulan dan Saran}

Mahasiswa FSMR ISI Yogyakarta memanfaatkan layanan perpustakaan sebagian besar untuk meminjam buku, dan mengerjakan tugas kuliah. Pencapaian IPK mahasiswa cukup tinggi dengan IPK terendah 2.83, tertinggi 3.91, dan ratarata 3.37. Pemanfaatan layanan perpustakaan mempunyai hubungan positif yang rendah dengan prestasi akademis mahasiswa. Artinya, pemanfaatan layanan perpustakaan tidak berpengaruh signifikan dengan prestasi akademis, besaran pengaruh tersebut sebesar $0.1 \%$. Mahasiswa FSMR, sesuai lingkup akademis yang dipelajari, mempunyai 
akses informasi yang luas sehingga prestasi mereka tidak hanya tergantung pada layanan perpustakaan. Dalam proses pembelajaran mereka dituntut menghasilkan karya akademis yang dipelajari dengan praktek langsung di lapangan. Responden juga memberi masukan yang berhubungan dengan peningkatan layanan perpustakaan. Masukan dari responden berkaitan dengan beberapa hal, yaitu: regulasi, layanan, koleksi, penyajian koleksi, dan fasilitas \& kenyamanan. Temuan ini dengan dimanfaatkan untuk menyusun kebijdengan layanan perpustakaan selanjutnya.

\section{Saran}

1. Perpustakaan perlu mengevaluasi kebijakan teknis yang berhubungan dengan kemudahan pemanfaatan koleksi oleh mahasiswa.

2. Perpustakaan perlu menjalin kerjasama yang baik dengan pihak fakultas (dosen) dalam rangka meningkatkan pemanfaatan layanan perpustakaan oleh mahasiswa.

3. Perpustakaan perlu mensosialisasi layanan konten digital selain di kegiatan orientasi mahasiswa baru, agar mahasiswa tertarik memanfaatkannya dalam menunjang kegiatan akademis mahasiswa.

4. Perpustakaan perlu berbenah dalam penyediaan layanan berbasis digital.

5. Perpustakaan perlu memprioritaskan pengadaan sarana dan prasarana yang memungkinkan mahasiswa dapat mengakses koleksi secara daring (online).

6. Staf perpustakaan diharapkan selalu meningkatkan layanan kepada mahasiswa dan lebih res- ponsif terhadap keinginan mahasiswa, terutama dalam menjalani komunikasi jarak jauh.

7. Seluruh staf secara bersama-sama untuk selalu memberikan layanan prima dan bersikap ramah serta terbuka terbuka dengan mahasiswa.

\section{Kepustakaan}

Agustiawan. 2018. Evaluasi Kualitas Layanan UPT Perpustakaan ISI Yogyakarta Berdasarkan Pedoman Survei Kepuasan Masyarakat Terhadap Penyelenggaraan Pelayanan Publik. Yogyakarta: Lembaga Penelitian Institut Seni Indonesia Yogyakarta

Afiah, Ismah. 2012. Korelasi Antara Potensi Akademik, Motivasi Belajar dengan Prestasi Akademik pada Siswa Kelas X Program Unggulan MAN Tambakberas Jombang. Tesis di Universitas Islam Negeri Maulana Malik Ibrahim. etheses.uin-malang.ac.id. Diakses tanggal 5 Mei 2020.

Istiana, Purwani. 2014. Layanan Perpustakaan. Ombak, Yogyakarta.

Mardiatuti, Aprilia; Uminurida Suciati; Winarsih. 2019. Pemanfaatan Media Viral untuk Memasarkan Produk dan Layanan Perpustakaan Universitas Gadjah Mada Menghadapi Era Industri 4.0 dalam Media Pustakawan Vol.26 No. 3 Tahun 2016, hal. 211-218.

Rodin, Rhodin. 2019. Analisis Kesiapan dan Tantangan Perpustakaan Perguruan Tinggi Islam di Indonesia Menghadapi Era 4.0 dalam Media Pustakawan Vol. 26, No. 2 Tahun 2019, hal. 82. 